\title{
EFEK ANTIOKSIDAN ASAP CAIR TERHADAP SIFAT FISIKO KIMIA IKAN GABUS (Ophiocephalus striatus) ASAP SELAMA PENYIMPANAN
}

\author{
Ernawati *) \\ *) Tenaga Pengajar Universitas Yudharta Pasuruan
}

\begin{abstract}
Abstrak
Daging ikan sangat mudah mengalami proses oksidasi, karena banyak mengandung asam lemak tak jenuh. Pengolahan ikan gabus dengan pengasapan cair akan memberikan antioksidan alami yaitu fenol yang terdapat pada komponen asap. Tujuan penelitian ini adalah untuk mendapatkan konsentrasi asap cair dan suhu pengeringan oven yang tepat agar menghasilkan ikan gabus asap yang bermutu baik selama penyimpanan. Penelitian menggunakan metode Rancangan Acak Kelompok (RAK) dengan dua faktor perlakuan yaitu perbedaan konsentrasi asap cair dan suhu pengeringan oven sebelum dan sesudah penyimpanan. Parameter yang diukur meliputi : kadar air, protein, lemak, fenol dan TBA, sedangkan pengujian organoleptik tingkat kesukaan meliputi warna, aroma, tekstur dan rasa dengan hedonic scale scoring. Hasil penelitian menunjukkan bahwa konsentrasi asap cair memberikan pengaruh nyata terhadap kadar fenol, TBA, rasa, warna, dan aroma, tapi tidak memberikan pengaruh nyata terhadap kadar air, protein dan lemak. Interaksi dari perlakuan konsentrasi asap cair dan suhu pengeringan berpengaruh terhadap warna. Dari hasil penelitian didapatkan perlakuan terbaik adalah konsentrasi asap cair $6 \%$ dan suhu pengeringan $60^{\circ} \mathrm{C}$.
\end{abstract}

Kata kunci : antioksidan, fenol, ikan gabus, penyimpanan

\section{Pendahuluan}

Ikan gabus atau dikenal secara lokal sebagai ikan kutuk adalah sejenis ikan buas yang hidup di air tawar. Ikan gabus biasa didapati di danau, rawa, sungai, dan saluran-saluran air hingga ke sawah-sawah, memangsa aneka ikan kecil-kecil, serangga, dan berbagai hewan air lain 
termasuk berudu dan kodok, serta kebanyakan dijual dalam keadaan segar dan merupakan sumber protein yang cukup penting bagi masyarakat (Agustini, 2006).

Potensi ikan gabus yang sudah mulai diketahui masyarakat adalah kaya akan albumin, yaitu salah satu jenis protein penting terbanyak di dalam plasma yang mencapai kadar $60 \%$ dan bermanfaat untuk pembentukan jaringan sel baru. Albumin dimanfaatkan untuk mempercepat pemulihan jaringan sel tubuh yang terbelah, misalnya karena operasi atau pembedahan (Suprayitno, 2009; Hasuki, 2008). Pemberian daging ikan gabus atau ekstrak proteinnya telah dicoba untuk meningkatkan kadar albumin dalam darah dan membantu penyembuhan beberapa penyakit (Anonim, 2002).

Sebagian masyarakat ada yang tidak menyukai rasa dan bau amis ikan gabus, sehingga perlu dilakukan usaha pengolahan untuk mengatasi bau amis tersebut. Menurut Rajen (2003), ikan gabus dibuat ekstrak dalam bentuk bubuk, sedangkan menurut Anonim (2008) ikan gabus juga dapat diolah dengan cara diasinkan atau diasap. Usaha pengolahan gabus dengan cara diasap kebanyakan masih dikerjakan secara tadisional, sedangkan penggunaan asap cair belum banyak dilakukan. Cara ini selain sederhana juga mudah diaplikasikan terhadap produk. Asap cair mengandung fenol yang bersifat antioksidan dan dapat menghambat oksidasi lipid pada ikan penyebab utama kerusakan mutu daging dan produk olahan daging selama penyimpanan.

Berdasarkan latar belakang tersebut, diberikan alternatif ikan gabus asap menggunakan asap cair yang dapat memberikan cita rasa khusus asap agar disukai masyarakat. Senyawa fenol yang dikandung dalam asap dapat berfungsi sebagai sumber antioksidan alami. Dari penelitian ini diharapkan dapat memberikan informasi bagi peneliti dan masyarakat tentang efek antioksidan dalam asap cair, sehingga kombinasi antioksidan dalam asap dan albumin dalam ikan gabus akan menambah nilai ekonomis ikan gabus sebagai pangan fungsional.

\section{Bahan dan Metode}

1. Bahan dan Alat

Bahan utama yang digunakan dalam penelitian ini adalah ikan gabus (Ophiocephalus striatus) ukuran 250 gram (4-5 ekor/kg), asap cair redistilasi dari tempurung kelapa, dan garam $\mathrm{NaCl}$. Bahanbahan kimia yang digunakan untuk 
analisis sampel dengan spesifikasi p.a (pro analisis) adalah: 1) $\mathrm{K}_{2} \mathrm{SO}_{4}$, $\mathrm{H}_{2} \mathrm{SO}_{4} \quad 95 \%, \quad \mathrm{H}_{2} \mathrm{O}_{2} \quad 30 \%$, $\mathrm{CuSO}_{4} .5 \mathrm{H}_{2} \mathrm{O}, \quad \mathrm{H}_{3} \mathrm{BO}_{3}$, pelarut chloroform, indikator metil merah, $\mathrm{HCl} \quad 0.2017 \mathrm{~N}$, pelarut lemak benzene, larutan $\mathrm{NaOH} 0.2 \mathrm{~N}$, Bromat bromide $0.2 \mathrm{~N}$, Kalium Iodida 15\%, indikator amilum, $\mathrm{Na}_{2} \mathrm{SO}_{3} \quad 0.1 \mathrm{~N}, \mathrm{HCl} 4 \mathrm{M}$, reagen TBA (0,02 M Thiobarbituric Acid dalam $90 \%$ asam asetat glacial). Bahan lain adalah kertas saring, plastik, . Bahan analisis dengan kemurnian teknis adalah aquadest.

\section{Alat}

Spektrofotometer UV-2100 (Unico), Oven merk MMM Medeenter dengan pengatur suhu. termometer. Alat yang digunakan untuk analisis : botol timbang, penjepit, desikator, timbangan analitik, labu kjeldahl, gelas erlenmeyer, labu destruksi, soxhlet, rotary

spektrofotometer, destilator.

\section{Metode Penelitian}

Metode yang digunakan adalah metode eksperiman rancangan acak kelompok (RAK) faktorial dengan 3 kali ulangan meliputi : kadar air, protein, lemak mengikuti metode AOAC (2005), fenol (Miliauskas, 2006) dan TBA (Tarladgis et al., 1960 dalam
Sudarmadji, 1997) sebelum dan sesudah penyimpanan. Pengujian organoleptik tingkat kesukaan meliputi warna, aroma, tekstur dan rasa dengan hedonic scale scoring diukur sebelum penyimpanan.

\section{Pelaksanaan Penelitian}

Penelitian ini meliputi beberapa tahapan yaitu : penyiangan ikan gabus dan pencucian untuk menghilangkan sisa-sisa kotoran dan lendir; Perendaman ikan dalam campuran larutan garam $10 \%$ dan asap cair dengan konsentrasi masing-masing $0 \%, 2 \%, 4 \%$, dan $6 \%$ selama 30 menit. Ikan diangkat dan ditiriskan selama 10 menit. Setelah penirisan ikan diatur di atas rak-rak kemudian dimasukkan dalam oven masing-masing pada suhu $50{ }^{\mathrm{O}} \mathrm{C}$, $60{ }^{\circ} \mathrm{C}$, dan $70{ }^{\circ} \mathrm{C}$, selama 10 jam. Setelah dilakukan pemanasan, ikan dibiarkan dingin. Sampel dianalisis secara obyektif dan subyektif kemudian dikemas dalam kemasan platik (cling wrap) dan disimpan pada suhu ruangan; Pengambilan sampel untuk analisis pada hari ke5 penyimpanan.

\section{Hasil dan Pembahasan}

Analisis Fisiko Kimia Ikan Gabus Asap

Analisis fisiko kimia ikan gabus asap akibat perbedaan 
konsentrasi asap cair dan suhu sesudah penyimpanan dapat dilihat pengeringan oven sebelum dan pada Tabel 1

Tabel 1. Rerata analisis fisiko kimia ikan gabus asap akibat perbedaan konsentrasi asap cair dan suhu pengeringan oven sebelum penyimpanan

\begin{tabular}{|c|c|c|c|c|c|c|c|c|c|c|c|c|}
\hline \multirow{5}{*}{ parameter } & \multicolumn{12}{|c|}{ Perlakuan } \\
\hline & \multicolumn{12}{|c|}{ Konsentrasi asap cair (\%) } \\
\hline & \multicolumn{3}{|c|}{0} & \multicolumn{3}{|c|}{2} & \multicolumn{3}{|c|}{4} & \multicolumn{3}{|c|}{6} \\
\hline & \multicolumn{12}{|c|}{ Suhu pengeringan $\left({ }^{\circ} \mathrm{C}\right)$} \\
\hline & 50 & 60 & 70 & 50 & 60 & 70 & 50 & 60 & 70 & 50 & 60 & 70 \\
\hline K. air & 51.71 & 49.92 & 48.95 & 50.06 & 49.44 & 48.25 & 51.37 & 49.63 & 47.52 & 55.04 & 50.22 & 47.70 \\
\hline $\mathrm{K}$. protein & 32.48 & 32.53 & 32.96 & 32.33 & 33.34 & 32.73 & 33.32 & 32.47 & 34.02 & 33.12 & 34.71 & 33.29 \\
\hline K. lemak & 7.93 & 8.78 & 8.30 & 8.79 & 7.14 & 8.63 & 8.51 & 8.84 & 8.73 & 8.80 & 8.56 & 8.95 \\
\hline K.fenol & 23.85 & 25.32 & 25.45 & 38.69 & 38.40 & 38.85 & 39.12 & 39.19 & 39.37 & 40.18 & 40.82 & 40.36 \\
\hline Nilai TBA & 1.31 & 1.20 & 1.08 & 1.10 & 1.12 & 1.03 & 0.99 & 0.92 & 0.99 & 0.98 & 0.94 & 0.94 \\
\hline warna & 6.52 & 6.48 & 6.42 & 5.83 & 6.10 & 6.55 & 6.95 & 7.27 & 7.15 & 6.90 & 6.48 & 6.75 \\
\hline aroma & 6.55 & 6.32 & 6.75 & 7.47 & 7.60 & 7.37 & 7.25 & 7.57 & 7.60 & 7.28 & 7.10 & 7.42 \\
\hline tekstur & 6.98 & 6.82 & 6.75 & 7.08 & 7.15 & 7.20 & 7.07 & 6.98 & 7.30 & 7.22 & 7.10 & 7.25 \\
\hline rasa & 5.87 & 5.88 & 5.80 & 5.83 & 6.18 & 5.90 & 6.23 & 7.03 & 6.98 & 5.92 & 5.82 & 5.47 \\
\hline
\end{tabular}

Kadar Air

Nilai kadar air ikan gabus asap akibat pengaruh konsentrasi asap cair dan suhu pengeringan oven yang berbeda sebelum penyimpanan berkisar antara $47.515 \%$ bb - $55.037 \%$ bb. (Tabel 1). Hasil analisis ragam menunjukkan bahwa perlakuan suhu pengeringan berpengaruh sangat nyata $(\rho=0.05)$ terhadap kadar air produk, sedangkan konsentrasi asap cair dan interaksi antar perlakuan tidak memberikan pengaruh nyata terhadap kadar air ikan gabus asap. Setelah disimpan selama 5 hari, kadar air ikan gabus asap berkisar antara $51.19 \%$ bb. sampai dengan $54.471 \%$ bb (Tabel 2). Perubahan kadar air ikan gabus asap sebelum dan sesudah penyimpanan disajikan pada Gambar 1. 
Tabel 2. Rerata analisis fisiko kimia ikan gabus asap akibat perbedaan konsentrasi asap cair dan suhu pengeringan oven setelah penyimpanan

\begin{tabular}{|c|c|c|c|c|c|c|c|c|c|c|c|c|}
\hline \multirow{5}{*}{ Parameter } & \multicolumn{12}{|c|}{ Perlakuan } \\
\hline & \multicolumn{12}{|c|}{ Konsentrasi asap cair (\%) } \\
\hline & \multicolumn{3}{|c|}{0} & \multicolumn{3}{|c|}{2} & \multicolumn{3}{|c|}{4} & \multicolumn{3}{|c|}{6} \\
\hline & \multicolumn{12}{|c|}{ Suhu pengeringan $\left({ }^{\circ} \mathrm{C}\right)$} \\
\hline & 50 & 60 & 70 & 50 & 60 & 70 & 50 & 60 & 70 & 50 & 60 & 70 \\
\hline K. air & 54.47 & 52.73 & 52.40 & 52.67 & 52.74 & 52.84 & 54.07 & 52.88 & 51.19 & 52.27 & 53.22 & 52.41 \\
\hline K. protein & 30.23 & 30.25 & 30.35 & 30.43 & 30.32 & 30.40 & 31.37 & 30.55 & 31.63 & 31.79 & 32.12 & 31.39 \\
\hline K. lemak & 7.20 & 8.06 & 7.60 & 8.12 & 6.73 & 8.26 & 8.24 & 8.28 & 8.23 & 8.16 & 8.10 & 8.42 \\
\hline K.fenol & 21.74 & 22.26 & 21.89 & 34.98 & 35.16 & 35.08 & 35.91 & 36.20 & 36.03 & 36.32 & 36.38 & 36.60 \\
\hline $\begin{array}{l}\text { Nilai } \\
\text { TBA }\end{array}$ & 9.51 & 9.36 & 9.51 & 7.58 & 8.10 & 7.63 & 6.05 & 6.08 & 6.36 & 4.82 & 4.15 & 5.29 \\
\hline
\end{tabular}

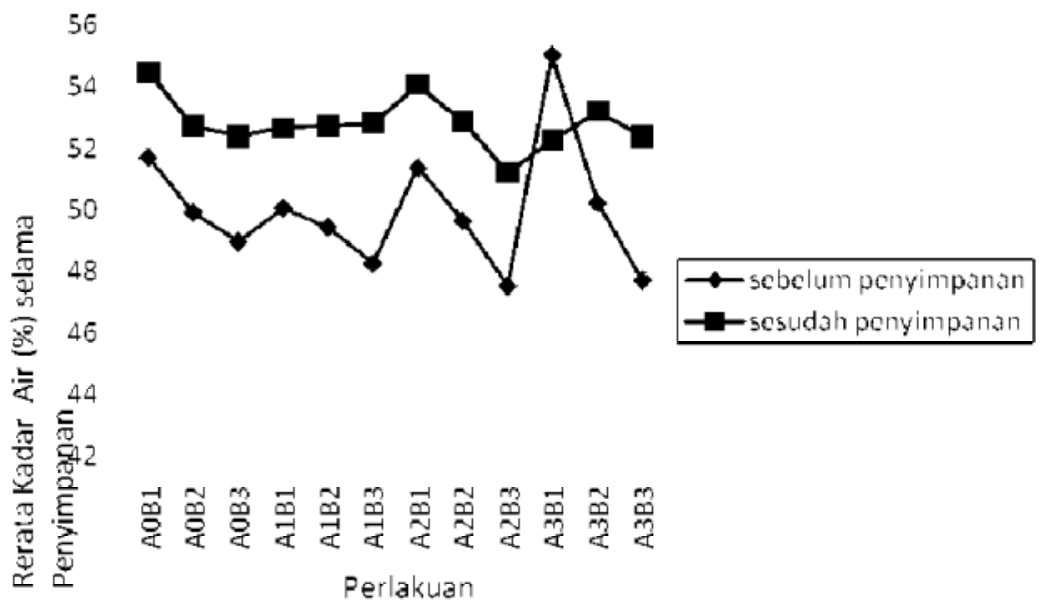

Gambar 1. Rerata Kadar Air (\% bb) Ikan Gabus Asap Sebelum dan Sesudah Penyimpanan 
Pada Gambar 1 terlihat adanya peningkatan kadar air ikan gabus asap selama penyimpanan. Hal ini disebabkan karena produk mengalami proses penurunan mutu. Proses penurunan mutu disebabkan oleh oksidasi lemak ikan yang mengandung berbagai asam lemak tidak jenuh, serta kandungan mineral pada garam seperti zat besi dan magnesium, yang dapat mempercepat oksidasi lemak (Supardi dkk, 1999). Selain itu selama penyimpanan terjadi peningkatan jumlah mikroorganisme. Menurut Adams et al. (2000) ketika mikroorganisme mulai tumbuh dan menjadi aktif, pada umumnya mereka menghasilkan air sebagai hasil akhir dari respirasi yang meningkatkan nilai kadar air.

\section{Kadar Protein}

Kadar protein ikan gabus asap dengan perlakuan konsentrasi asap dan suhu pengeringan oven yang berbeda berkisar antara $32.32 \%$ $34.59 \%$. Hasil analisis keragaman kadar protein menunjukkan bahwa konsentrasi asap cair, suhu pengeringan dan interaksi keduanya tidak memberikan pengaruh nyata $(\rho=0.05)$. Kadar protein tertinggi diperoleh dari perlakuan konsentrasi asap cair 4\% dan suhu pengeringan $70^{\circ} \mathrm{C}$, sedangkan kadar protein terendah diperoleh dari perlakuan konsentrasi asap cair $2 \%$ dan suhu pengeringan $70^{\circ} \mathrm{C}$. Kadar protein ikan gabus asap setelah penyimpanan selama 5 hari pada suhu ruangan berkisar antara $30.23 \%$ - 32.12\% . Perubahan kadar protein ikan gabus asap sebelum dan sesudah penyimpanan disajikan pada Gambar 2. 


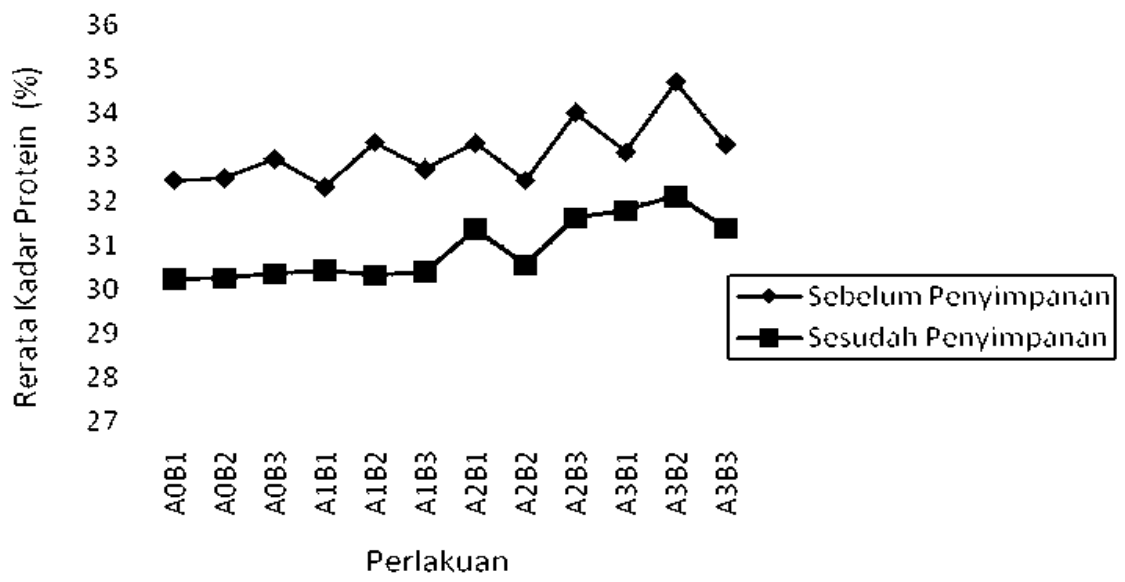

Gambar 2. Rerata Kadar Protein (\%) Ikan Gabus Asap Sebelum dan Sesudah Penyimpanan

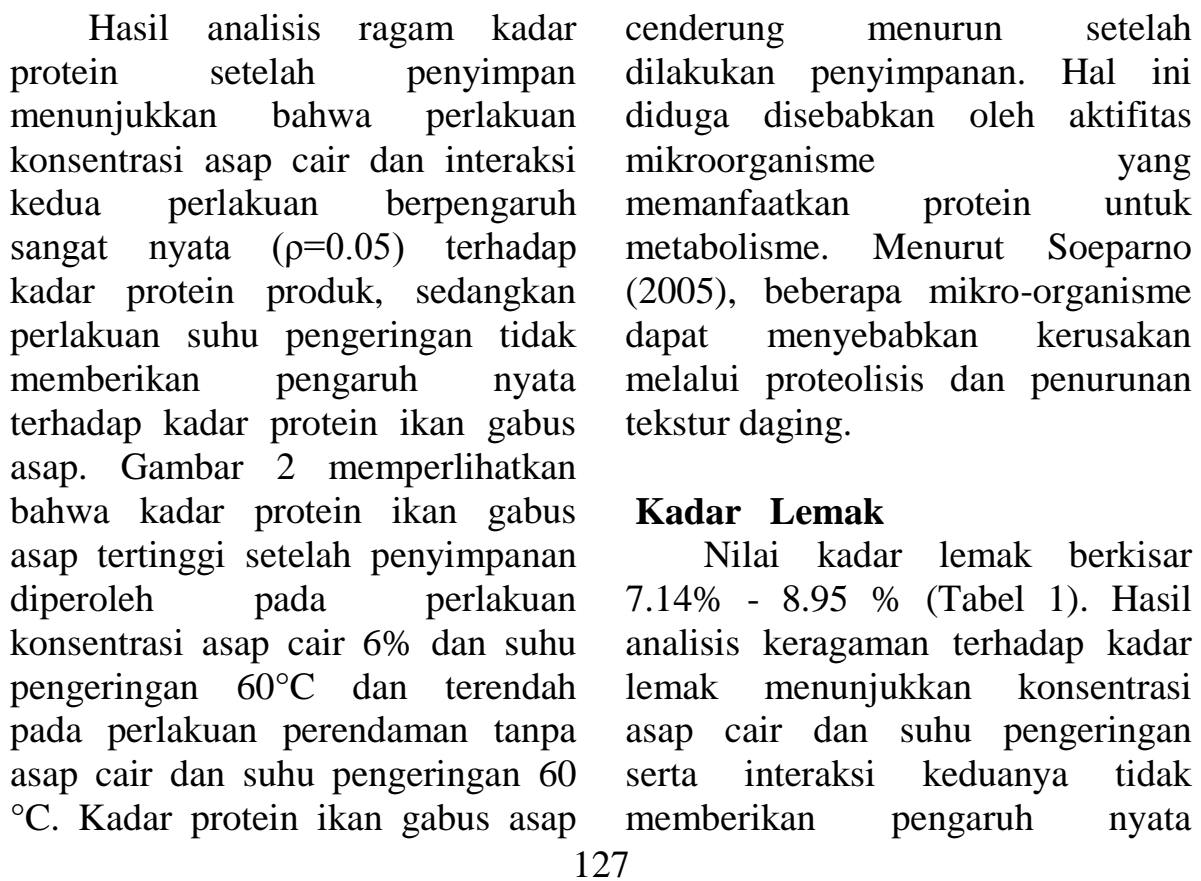


$(\rho=0.05)$. Besarnya konsentrasi bertindak sebagai donor hidrogen asap cair dan tingginya suhu dan dalam jumlah yang kecil efektif pengeringan tidak mempengaruhi kadar lemak ikan gabus asap. Hal ini disebabkan dalam asap cair tidak terkandung bahan-bahan yang bisa menambah atau mengurangi kadar lemak produk. Menurut Pokorny (2001), di dalam asap cair terkandung senyawa yang bisa mencegah terjadinya oksidasi pada lemak. Antioksidan pada asap karena terdapat senyawa fenol yang mencegah reaksi oksidasi.

Nilai kadar lemak ikan gabus asap setelah dilakukan penyimpanan dalam suhu ruangan selama 5 hari berkisar antara $6.73 \%$ - 8.42\% (Tabel 2). Perubahan kadar lemak ikan gabus asap sebelum dan sesudah penyimpanan disajikan pada Gambar 3.

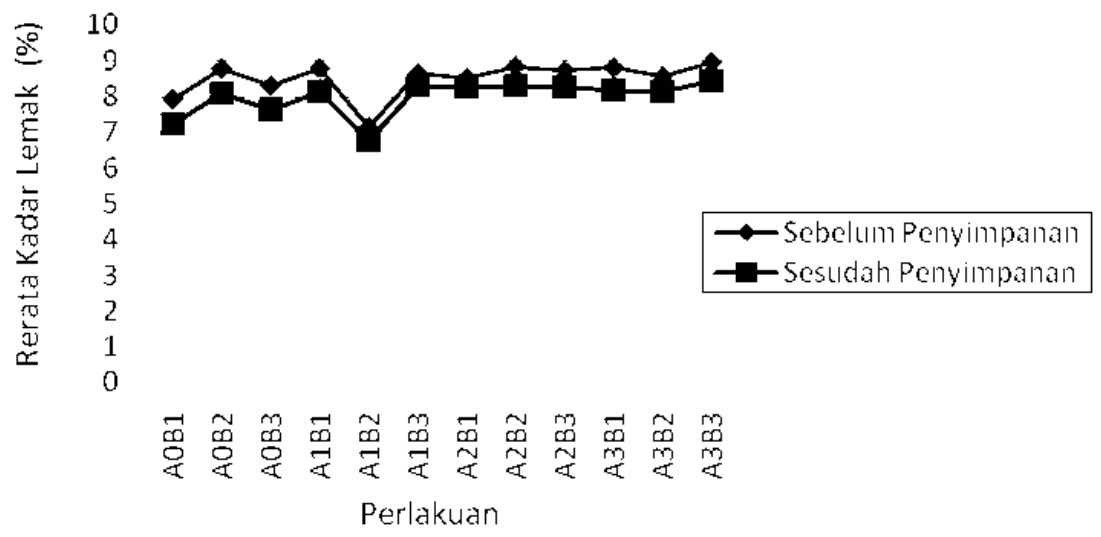

Gambar 3. Rerata Kadar Lemak Ikan Gabus Asap Sebelum dan Sesudah Penyimpanan

Gambar 3 memperlihatkan menurunkan kadar lemak. Hasil bahwa selama penyimpanan kadar analisis ragam kadar lemak setelah lemak cenderung menurun. penyimpan menunjukkan bahwa Kandungan air yang tinggi pada perlakuan konsentrasi asap cair dan bahan menyebabkan terjadinya suhu pengeringan serta interaksi reaksi hidrolisis sehingga kedua perlakuan berpengaruh 
sangat nyata $(\alpha=0.05)$ terhadap kadar lemak produk.

\section{Kadar Fenol}

Senyawa fenol sangat penting dalam produk asap, karena fenol berperan dalam menyumbangkan aroma dan rasa spesifik produk asapan (Guillen et al, 2002). Maga (1987) menyatakan fenol dengan titik didih yang lebih tinggi akan menunjukkan sifat antioksidan yang lebih baik jika dibandingkan dengan senyawa fenol yang bertitik didih rendah.

Nilai kadar fenol ikan gabus asap berkisar antara $23.85 \mathrm{ppm}$ 40.36 ppm (Tabel 1). Hasil analisis keragaman terhadap kadar fenol menunjukkan konsentrasi asap cair memberikan pengaruh yang sangat nyata $\quad(\rho=0.05), \quad$ sedangkan perbedaan suhu pengeringan dan interaksi kedua perlakuan tidak memberikan pengaruh nyata. Konsentrasi asap cair $6 \%$ memberikan nilai kadar fenol paling besar, sedangkan perlakuan tanpa asap cair menunjukkan nilai kadar fenol terendah.

Menurut Guillen et al. (2001), sebagian besar senyawa teridentifikasi dalam komponen asap diantaranya adalah turunan fenol, asam, aldehid, keton, turunan alkohol, senyawa terpenic dan alkil aril eter. Kadar fenol akan semakin meningkat seiring bertambahnya konsentrasi asap cair. Adanya senyawa fenol dalam asap cair memberikan sifat antioksidan terhadap fraksi lemak dalam produk asapan. Lebih lanjut Guillen et al., (2000) menyebutkan senyawa fenolat dapat berperan sebagai donor hidrogen dan efektif dalam jumlah sangat kecil untuk menghambat autooksidasi lemak

Nilai kadar fenol ikan gabus asap setelah dilakukan penyimpanan dalam suhu ruangan selama 5 hari berkisar antara 23.85 ppm - 40.82 ppm (Tabel 2). Perubahan kadar fenol ikan gabus asap sebelum dan sesudah penyimpanan disajikan pada Gambar 4. 


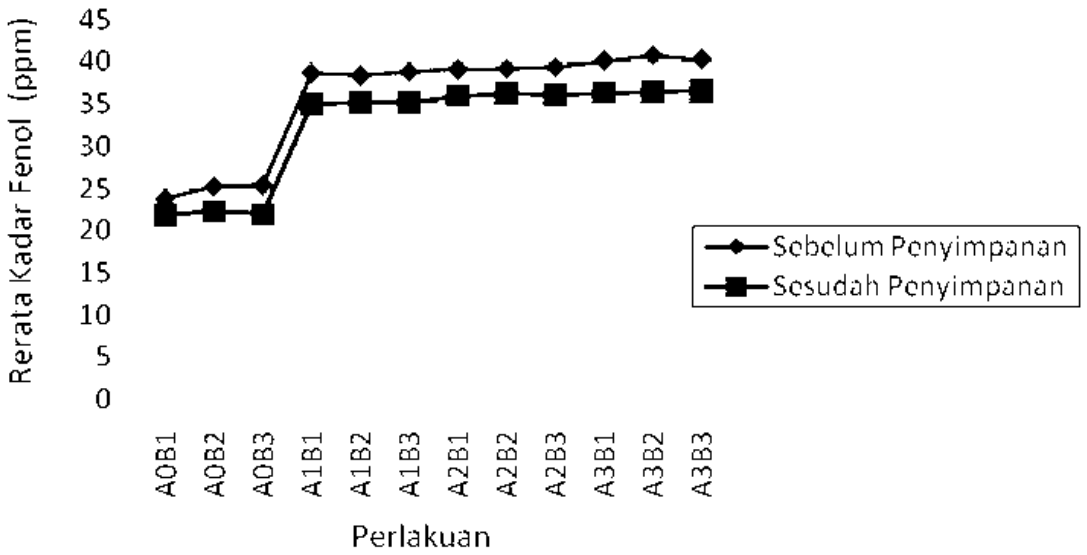

Gambar 4. Rerata Kadar Fenol Ikan Gabus Asap Sebelum dan Sesudah Penyimpanan

Gambar 4 menunjukkan bahwa selama penyimpanan kadar fenol cenderung menurun. Menurut Sundari (2008) penurunan tersebut disebabkan fenol menguap akibat proses penyimpanan pada suhu ruang. Pada perlakuan tanpa penambahan asap cair terdapat kandungan fenol, hal ini disebabkan adanya senyawa fenol yang terdapat dalam air dan garam yang ditambahkan. Hasil analisis keragaman terhadap kadar fenol setelah penyimpanan menunjukkan konsentrasi asap cair memberikan pengaruh yang sangat nyata $(\rho=0.05)$, sedangkan perbedaan suhu pengeringan dan interaksi kedua perlakuan tidak memberikan pengaruh nyata.

Konsentrasi asap cair 6\% memberikan nilai kadar fenol paling besar yaitu 36.43 ppm, sedangkan perlakuan tanpa asap cair menunjukkan nilai kadar fenol terendah yaitu $21.96 \mathrm{ppm}$. Girard (1992), menyatakan bahwa jumlah batas aman dalam produk pengasapan berkisar dari 0,06 $\mathrm{mg} / \mathrm{kg}$ sampai $5000 \mathrm{mg} / \mathrm{kg}$ atau 6 ppm sampai 5000 ppm $(0,0006-$ $0,5 \%$ ). Dengan demikian, kandungan fenol dalam ikan gabus asap dengan penambahan asap cair ini masih dalam batas aman tersebut. Fenol mempunyai sifat asam, mudah dioksidasi, mudah 
menguap, sensitif terhadap cahaya dalam asap cair efektif untuk dan oksigen, serta bersifat menghambat oksidasi lipid pada antiseptik. Penurunan kadar fenol antara lain disebabkan perlakuan pencucian, perebusan, dan proses pengolahan lebih lanjut untuk dijadikan produk yang siap dikonsumsi (Sundari, 2008).

\section{Nilai TBA}

Nilai TBA ikan gabus asap berkisar antara $0.92 \quad \mathrm{mg}$ malonaldehid/kg sampai dengan $1.311 \mathrm{mg}$ malonaldehid/kg (Tabel 1). Hasil analisis keragaman terhadap nilai TBA menunjukkan konsentrasi asap cair memberikan pengaruh yang sangat nyata $(\rho=0.05)$, sedangkan perbedaan suhu pengeringan memberikan pengaruh nyata dan interaksi kedua perlakuan tidak berpengaruh nyata. Hal ini disebabkan perendaman ikan gabus asap. Makin tinggi konsentrasi asap cair, makin besar efek antioksidannya, sedangkan semakin tinggi suhu pengeringan maka kadar TBA semakin rendah. Kenaikan suhu pengeringan akan semakin mengurangi kadar air bahan, sehingga kadar air menurun. Penurunan kadar air mengurangi terjadinya kerusakan lemak oleh aksi mikroba sehingga nilai TBA dapat ditekan.

Nilai TBA ikan gabus asap setelah penyimpanan dalam suhu ruangan selama 5 hari berkisar antara $\quad 4.152 \quad-\quad 9.507 \quad \mathrm{mg}$ malonaldehid/kg (Tabel 2). Perubahan nilai TBA ikan gabus asap sebelum dan sesudah penyimpanan disajikan pada Gambar 5. 


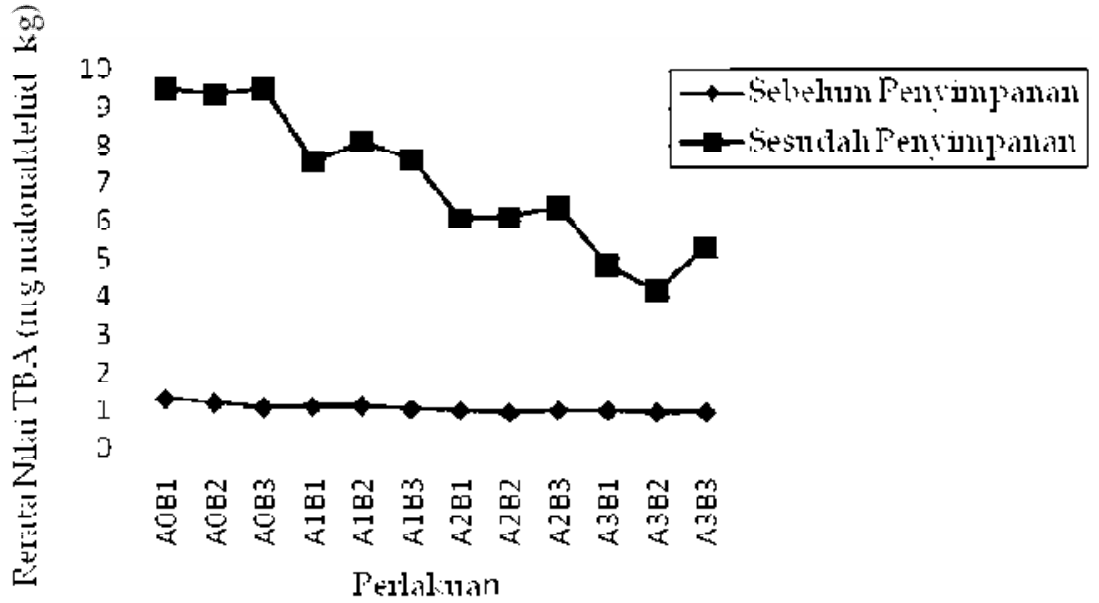

Gambar 5. Rerata Nilai TBA Ikan Gabus Asap Sebelum dan Sesudah Penyimpanan

Hasil analisis keragaman dikonsumsi oleh manusia sebaiknya terhadap nilai TBA setelah kurang dari $3 \mathrm{mg}$ malonaldehid/kg. penyimpanan menunjukkan konsentrasi asap cair dan interaksi kedua perlakuan memberikan pengaruh yang sangat nyata $(\rho=0.05)$, sedangkan perbedaan suhu pengeringan memberikan pengaruh nyata. Nilai TBA terendah diperoleh dari perlakuan konsentrasi asap cair 6\% dan suhu pengeringan $70{ }^{\circ} \mathrm{C}$, sedangkan nilai TBA tertinggi adalah perlakuan perendaman tanpa asap cair dan suhu pengeringan $70{ }^{\circ} \mathrm{C}$. Menurut Apriliani (2010) dalam Rizki dkk (2009), batas tertinggi nilai TBA untuk produk yang masih Hasil penelitian ini memperlihatkan bahwa kandungan TBA ikan gabus asap pada setiap perlakuan yang disimpan selama 5 hari pada suhu ruangan sudah tidak layak dikonsumsi. Hal ini kemungkinan disebabkan kandungan protein dan lemak ikan gabus cukup tinggi yaitu masing-masing sekitar $33.11 \%$ dan $8.5 \%$, sehingga konsentrasi asap cair yang diberikan belum sepenuhnya dapat menekan nilai TBA. 


\section{Nilai Warna}

Warna berperanan penting dalam penerimaan makanan, serta dapat memberi petunjuk mengenai perubahan kimia dalam makanan. Fennema (1996) menambahkan, warna menjadi atribut kualitas yang paling penting. Meskipun suatu produk bernilai gizi tinggi, rasa enak dan tekstur baik, namun jika warna kurang menarik membuat produk tersebut kurang diminati. Nilai organoleptik warna ikan gabus asap akibat pengaruh konsentrasi asap cair dan suhu pengeringan oven yang berbeda berkisar antara 5.83 sampai dengan 7.27 (Tabel 1).

Hasil analisis keragaman terhadap nilai kesukaan warna menunjukkan bahwa konsentrasi asap cair dan interaksi antara kedua perlakuan memberikan pengaruh sangat nyata dengan uji Duncans $(\rho=0.05)$, sedangkan perlakuan suhu pengeringan tidak berpengaruh. Perlakuan perendaman asap cair $2 \%$ dan 60 ${ }^{\circ} \mathrm{C}$ mempunyai nilai kesukaan warna tertinggi, sedangkan kesukaan warna terendah diperoleh dari perlakuan perendaman tanpa asap cair dan suhu pengeringan 50 ${ }^{\circ} \mathrm{C}$. Hal ini disebabkan semakin besar konsentrasi asap yang diberikan maka komponen asap yang meresap ke dalam daging ikan gabus semakin banyak, sehingga warna produk semakin coklat dan banyak disukai oleh panelis. Warna coklat tersebut disebabkan senyawa karbonil. Jenis karbonil yang terdapat dalam asap cair antara lain adalah vanillin dan syring-aldehyde (Moejiharto dkk, 2000).

\section{Nilai Aroma}

Nilai organoleptik aroma ikan gabus asap akibat pengaruh konsentrasi asap cair dan suhu pengeringan oven yang berbeda berkisar antara 6.32 sampai dengan 7.60 (Tabel 1). Hasil analisis keragaman terhadap nilai aroma menunjukkan konsentrasi asap cair memberikan pengaruh yang sangat nyata $\quad(\rho=0.05), \quad$ sedangkan perbedaan suhu pengeringan dan interaksi kedua perlakuan tidak memberikan pengaruh nyata.

Nilai kesukaan tertinggi terhadap aroma terdapat pada perlakuan konsentrasi asap cair $4 \%$. Hal ini disebabkan semakin pekatnya asap cair yang digunakan sebagai perendam, maka komponen asap yang menempel atau meresap ke dalam ikan gabus asap semakin banyak. Bau khas tersebut adalah fenol yaitu senyawa utama pembentuk aroma asap (Dwiyitno dkk, 2006; Soeparno, 2005). Pada perlakuan konsentrasi asap cair $6 \%$, nilai kesukaan terhadap aroma 
mulai menurun karena bau asap makin menyengat sehingga kurang disukai panelis. Lebih lanjut Moejiharto dkk (2000) menjelaskan bahwa besarnya kadar fenol berhubungan dengan semakin besarnya konsentrasi perendaman. Hal ini dapat dijelaskan bahwa difusi asap cair (fenol) dari permukaan ke pusat sampel berjalan sesuai dengan besarnya konsentrasi yang diberikan.

\section{Nilai Tekstur}

Nilai kesukaan terhadap tekstur ikan gabus asap akibat pengaruh konsentrasi asap cair dan suhu pengeringan oven yang berbeda berkisar antara 6.75 sampai dengan 7.30 (Tabel 1) . Nilai tekstur ikan gabus asap terendah didapat pada perlakuan perendaman tanpa asap cair dan suhu pengeringan $70{ }^{\circ} \mathrm{C}$, sedangkan nilai tekstur tertinggi pada perlakuan perendaman asap cair $4 \%$ dan suhu pengeringan $70{ }^{\circ} \mathrm{C}$.

Hasil analisis keragaman nilai tekstur menunjukkan konsentrasi asap cair, perbedaan suhu pengeringan dan interaksi kedua perlakuan tidak memberikan pengaruh nyata pada uji Duncan $(\rho=0.05)$. Hal ini disebabkan tekstur bersifat subjektif dan menimbulkan pendapat yang berbeda-beda dalam menilai kualitas yaitu perbedaan sensifitas dalam merasa dan meraba. Menurut Estiasih (2011), faktor yang mempengaruhi tekstur ikan asap adalah suhu pengasapan. Pada pemakaian suhu pengasapan yang tinggi akan mempercepat terjadinya penggumpalan protein, sehingga tekstur daging lebih kompak. Dari hasil analisis keragaman perlakuan suhu pengeringan tidak memberikan pengaruh nyata, tapi secara umum terlihat bahwa semakin tinggi suhu pengeringan, maka nilainya cenderung meningkat.

\section{Nilai Rasa}

Nilai organoleptik rasa ikan gabus asap akibat pengaruh konsentrasi asap cair dan suhu pengeringan oven yang berbeda berkisar antara 5.47 sampai dengan 7.03. (Tabel 1). Hasil analisis keragaman nilai rasa menunjukkan konsentrasi asap cair memberikan pengaruh sangat nyata $(\rho=0.05)$, sedangkan perbedaan suhu pengeringan dan interaksi kedua perlakuan tidak memberikan pengaruh nyata. Konsentrasi asap cair $4 \%$ memberikan nilai kesukaan rasa tertinggi, sedangkan nilai rasa terendah diperoleh dari konsentrasi asap cair 6\%. Menurut Refilda (2008), pemberian konsentrasi asap cair pada ikan berpengaruh nyata pada kesukaan panelis karena 
memberikan flavor khas, yang disebabkan oleh senyawa karbonil yang memberikan pengaruh cita rasa spesifik pada ikan gabus asap, sehingga rasa amis ikan dapat tertutupi. Komponen dalam asap cair yang dapat menimbulkan rasa sedap pada produk yaitu formaldehide dan furaldehide (Darmadji, 2009).

\section{Kesimpulan}

- Perlakuan konsentrasi asap cair yang berbeda berpengaruh sangat nyata terhadap nilai kadar fenol, TBA, serta nilai organoleptik rasa, warna dan aroma, tetapi tidak berpengaruh nyata terhadap nilai kadar air, protein, lemak dan nilai organoleptik tekstur.

- Perlakuan konsentrasi asap cair setelah penyimpanan berpengaruh sangat nyata terhadap nilai kadar protein, lemak, fenol, TBA, serta nilai organoleptik rasa, warna dan aroma, tetapi tidak berpengaruh nyata terhadap nilai kadar air, dan nilai organoleptik tekstur.

- Perlakuan suhu pengeringan yang berbeda berpengaruh nyata terhadap nilai kadar air, TBA, serta nilai organoleptik warna, tetapi tidak berpengaruh nyata terhadap nilai kadar protein, lemak, fenol dan nilai organoleptik rasa, aroma dan tekstur.

- Perlakuan suhu pengeringan yang berbeda setelah penyimpanan berpengaruh nyata terhadap nilai kadar air, lemak, TBA, serta nilai organoleptik warna, tetapi tidak berpengaruh nyata terhadap nilai kadar protein, fenol serta nilai organoleptik rasa, aroma dan tekstur.

- Perlakuan terbaik dalam penelitian berdasarkan sifat fisiko kimianya adalah konsentrasi asap cair 6\% dan suhu pengeringan $60^{\circ} \mathrm{C}$

Saran

- Berdasarkan hasil penelitian, untuk mendapatkan ikan gabus asap yang mempunyai kualitas yang baik berdasarkan sifat fisiko kimianya disarankan menggunakan konsentrasi asap cair $6 \%$ dan suhu pengeringan $60^{\circ} \mathrm{C}$.

- Perlunya dilakukan penelitian lanjutan tentang umur simpan ikan gabus asap pada suhu ruangan maupun suhu rendah.

DAFTAR PUSTAKA

Adams MR, Moss M.O. 2002. Food Microbiology.

Second 
Edition. Royal Society of Chemistry. UK

Agustini D. 2006. Pengaruh Pemberian Fish Albumin Ikan Gabus (Ophiocephalus striatus). Tenggiri

(Scomberomerus guttatus). Tongkol (Euthynnus affinis). dan ikan Kuniran (Upeneus Sulphureus) terhadap Penutupan Luka pada Hewan Uji Tikus Putih Wistar (Rattus novergicus). Universitas Brawijaya. Malang.

Anonim. 2002. Potensi Serum Albumin Ikan Gabus. http://sariikankutuk.com/ index.php?option=com_cont ent\&view $=$ article $\& \mathrm{id}=50 \&$ Itemid $=62$

Anonim. 2008. Potensi Industri Ikan Gabus Asin. http://foragri.blogsome.com/ potensi-industri-ikangabus-asin/

AOAC. 2005. Official Methods of Analysis. Association of Official Analytical Chemists. Benjamin Franklin. Washington. DC Apriliani D. 2010. Analisis Kadar Thiobarbituric Acid dan Benzo (a) pyrene pada Ikan Nila (Oreochromis niliticus) Asap Menggunakan Asap Cair
Bonggol Jagung dan Tempurung Kelapa. Tesis. Universitas Diponegoro. Semarang

Darmadji P. 2009. Teknologi Asap Cair dan Aplikasinya pada Pangan dan Hasil Pertanian. Universitas Gadjah Mada. Yogyakarta

Etiasih T, Ahmadi. 2011. Teknologi Pengolahan Pangan. Penerbit Bumi Aksara. Jakarta

Fennema OR. 1996. Food Chemistry. Marcel Dekker. Inc. New York

Gard JP. 1992. Smoking in Technology of Meat and Meat Products. J.P. Girard (ed).Ellis Horwood. New York.

Guillen MD, P Sopelana and MA Partearroyo. 2000. Polycyclic aromatic hydrocarbons in liquid smoke flavorings obtained from different types of wood, effect of storage in polyethylene flasks on their concentrations. Journal of Agricultural and Food Chemistry. 48: 50836087.

Guillen MD, and Manzanos MJ. 2002. Study of The Volatile 
Composition of An Aqueous Oak Smoke Preparation. Food Chem. 79: 283-292.

Hasuki. 2008. Cepat Sembuh Berkat Ikan Gabus. http://www.tabloidnakita.com/

Maga JA. 1987. Smoke In Food Processing. CRC Press. Inc. Boca Raton. Florida. 12-13 pp

Moejiharto, Chamidah A, dan Tri

E. 2000. Pengaruh lama Perendaman dan

Penyimpanan

Ikan

Bandeng Asap dengan Larutan Asap Cair

Terhadap Nilai Aw, tekstur, Organoleptik dan Mikrobiologi. Universitas Brawijaya. Malang.

Pokorny J, Yanishlieva N, Gordon

M. 2001. Antioxidants in Food. Woodhead

Publishing Limited.

Abington Hall. Abington Cambridge CB1 6AH

Rajen M. 2003. Ikan Mempercepat Penyembuhan Luka. Halistik Medicine. The Star Refilda, Indrawati.

2008.

Penyuluhan Penggunaan

Garam dan Asap Cair Untuk Menambah Cita Rasa dan Kualitas Ikan Bilih (Mystacoleuseus padangensis) Dari Danau Singkarak Dalam Meningkatkan

Perekonomian Rakyat. DP2M Dikti Depdiknas Program IPTEKS. Fakultas MIPA Universitas Andalas

Rizki A, Rochima, E. 2009. Pengaruh Suhu Pengeringan Terhadap Karakteristik Kimiawi Filet Lele Dumbo Asap Cair Pada Penyimpanan Suhu Ruang. Jurnal Bionatura. 11(1): 21-36. Universitas Padjadjaran. Bandung

Soeparno. 2005. Ilmu dan Teknologi Daging Cetakan keempat. Gadjah Mada University Press. Yogyakarta. 200-206 231247

Sudarmadji S, Haryono B, Suhardi. 1997. Prosedur Analisa Untuk Bahan Makanan dan Pertanian. Penerbit Liberty. Yogyakarta

Sundari T. 2008. Potensi Asap Cair Tempurung Kelapa Sebagai Alternatif Pengganti Hidrogen Peroksida $\left(\mathrm{H}_{2} \mathrm{O}_{2}\right)$ Dalam Pengawetan Ikan Tongkol (Euthynnus affinis).UNS. Surakarta.

Supardi, Imam, Sukamto. 1999. Mikrobiologi Dalam Pengolahan

Dan 
Keamanan

Bandung.

Suprayitno E. 2009. Penggunaan Albumin Ikan Gabus (Ophiocephalus Striatus) Pada Penutupan Luka. http://profeddys.blogspot.co $\mathrm{m} / 2009 / 02 /$ penggunaanalbumin-ikan-gabus.html Tarladgis BG, Watts BM, Younathan MT. 1960. A Distillation Method for The Quantitative Determination of Malonaldehyde in Rancid Foods. Journal Amer. Oil Chem. Soc. 37:44

Yamada K, Mito N, Nagata J, Umegaki K.. 2008. Health claim evidence requirements in Japan. The Journal of Nutrition (American Society for Nutrition) 138: 1192S-1198S. 